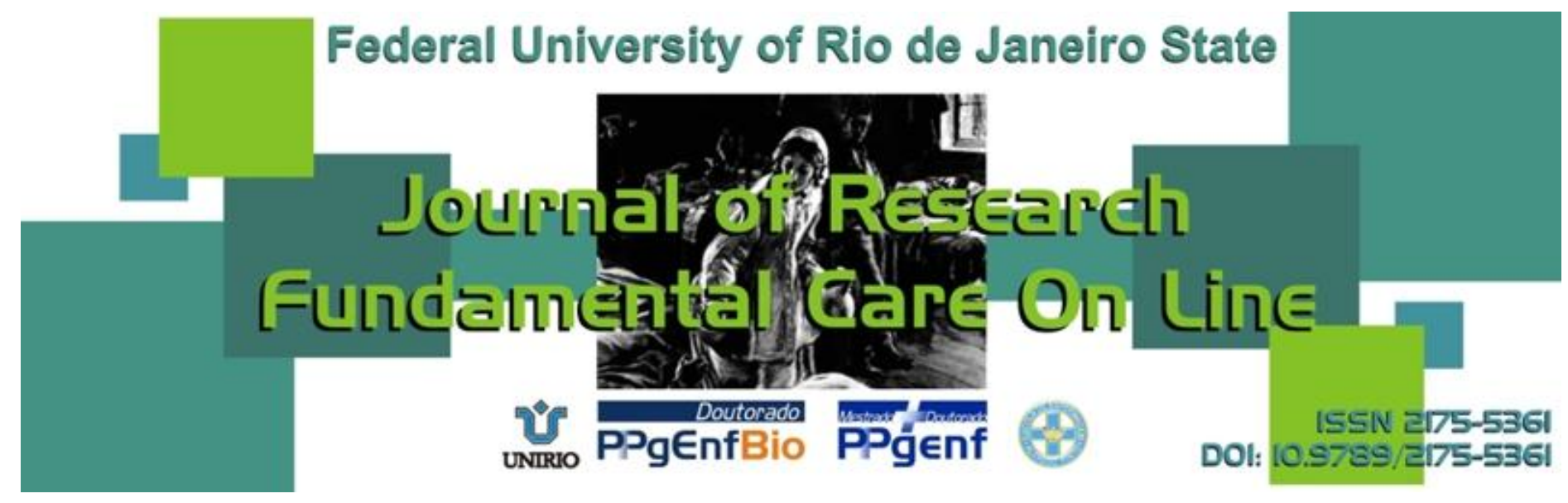

\title{
RESEARCH
}

\section{THE SUPPORT OF THE COMPANION CHOOSEN BY THE PREGNANT MOTHER IN A MATERNITY SCHOOL}

\section{APOIO À PARTURIENTE POR ACOMPANHANTE DE SUA ESCOLHA EM UMA MATERNIDADE-ESCOLA}

\section{EL APOYO PRESTADO POR EL ACOMPAÑANTE SELECCIONADO POR LA PARTURIENTA EN UNA MATERNIDAD ESCUELA}

Marcela Caetano Alves ${ }^{1}$, Odaléa Maria Brüggemann ${ }^{2}$, Ricardo Roberto Bampi ${ }^{3}$, Viviane Gonzaga Godinho ${ }^{4}$

\begin{abstract}
Objective: To understand the inclusion of the companion support in the obstetric ward and to identify the actions developed to support the pregnant mother during labor, delivery and immediate postpartum. Method: An exploratorydescriptive study with a qualitative approach. Data was collected from September to November 2011, through unstructured participant observation with 17 companions, which remained in the obstetric center of a maternity school. Data analysis followed the procedures of apprehension, synthesis, theorization and transfer. Results: Five categories emerged: Aspects related to the inclusion of the companion in the obstetric ward; actions of support of the partner during labor; the role of the partner at delivery; first contact of the partner with of the newborn; and the accompanying interaction with the binomial in the immediate postpartum period. Conclusion: The companion develops actions of support in all clinical delivery periods; however, it has greater autonomy and feels more confident in the pre-partum. Descriptors: Humanizing delivery; Delivery rooms, Patient escort service, Obstetrical Nursing, Social support.
\end{abstract}

\section{RESUMO}

Objetivo: Compreender a inserção do acompanhante no centro obstétrico e identificar as ações de apoio à parturiente desenvolvidas no trabalho de parto, parto e pós-parto imediato. Método: Trata-se de uma pesquisa exploratóriodescritiva, com abordagem qualitativa. Os dados foram coletados de setembro a novembro de 2011, por meio de observação participante não estruturada com 17 acompanhantes, que permaneceram no centro obstétrico de uma maternidade-escola. A análise dos dados foi pelo processo de apreensão, síntese, teorização e transferência. Resultados: Emergiram cinco categorias: Aspectos relacionados com a inserção do acompanhante no centro obstétrico; As ações de apoio do acompanhante no pré-parto; O papel do acompanhante no momento do parto; O primeiro contato do acompanhante com o recém-nascido e A interação do acompanhante com o binômio no pós-parto imediato. Conclusão: 0 acompanhante desenvolve ações de apoio em todos os períodos clínicos do parto, no entanto, tem maior autonomia e sente-se mais confiante no pré-parto. Descritores: Parto humanizado, Salas de parto, Acompanhantes de pacientes, Enfermagem obstétrica, Apoio social.

\section{RESUMEN}

Objetivo: Comprender la inserción del acompañante en el Centro-Obstétrico e identificar el apoyo hacia la parturienta durante el trabajo de parto, parto y post-parto inmediato. Método: Estudio exploratorio-descriptivo, con enfoque cualitativo. Los datos fueron recolectados entre septiembre y noviembre de 2011, a través de observación participante no estructurada con 17 acompañantes, que permanecieron en la unidad de obstetricia de una maternidad-escuela. Los datos fueron analizados por el proceso de aprensión, síntesis, teorización y transferencia. Resultados: Surgieron cinco categorías: Aspectos relacionados con la inserción del acompañante en el centro obstétrico, Acciones de contacto del acompañante en el pre-parto, Papel del acompañante durante el parto, Primer contacto del acompañante con el recién nacido e Interacción del acompañante con el binomio en el post-parto inmediato. Conclusión: el acompañante desarrolla acciones de apoyo en todo los periodos clínicos del parto, sin embargo, tiene mayor autonomía y se siente más seguro en el pre-parto. Descriptores: Parto humanizado, Salas de parto, Acompañantes de pacientes, Enfermería obstétrica, Apoyo social.

${ }^{1}$ Nurse, Graduated from the Federal University of Santa Catarina (UFSC).E-mail: marcicaetano@hotmail.com. ${ }^{2}$ Obstetric Nurse. PHD in Tocogynecology. Professor at the Nursing Department and the Nursing Post-graduate Programme from the Federal University of Santa Catarina (UFSC). Researcher from the CNPq. E-mail: odalea@ccs.ufsc.br. Address: Deputado Antônio Edu Vieira Street, $n^{\circ}$ 1020, Apartment 204, Bloco B, Pantanal Neighborhood.Florianópolis/SC - ZIP Code 88040-001. ${ }^{3}$ Nurse, Graduated from the Federal University of Santa Catarina (UFSC).E-mail: ricardorb87@hotmail.com. ${ }^{4}$ Nurse, Graduated from the Federal University of Santa Catarina (UFSC).E-mail: godinho.viviane@hotmail.com.

J. res.: fundam. care. online 2013. jul./set. 5(3):153-164 


\section{INTRODUCTION}

In the past, childbirth care was exclusively a female responsibility, given that midwives carried out such a process. The birth process occurred in the residence itself of the mother, in the presence of family members who were usually women. ${ }^{1}$

Slowly, from the XVI century, childbirth care was being undertaken by doctors and started to be institutionalized, then the obstetrician became the center of the scene. With that, the woman is no longer the protagonist in the childbirth scene, ceased choosing the position she wanted to give birth and, mainly, realized her loved ones were taken away from the childbirth environment. ${ }^{2}$ In contrast, the medicine offers a seemingly safety childbirth to the woman and her son. ${ }^{3}$

Because of the need for changes in childbirth care, the World Health Organization (WHO), in 1996, launched a stream in favor of a new obstetric practice based on scientific evidence, which was widely emphasized in health institutions, which highlights the respect to the woman's choice about their companions during the pre-birth and the childbirth itself. ${ }^{4}$

The empathic support from service providers and companions towards the parturients, before and during the labor, can reduce the need for pharmacological analgesia and, consequently, provide a better experience of giving birth. For many women, a shower bath or of immersion significantly reduces the pain. Touchs and massages performed by companions are also usually effective for reducing the painful sensation. ${ }^{4}$

Among the activities carried out by companions are measures of physical comfort and emotional support, which are: walking with the parturient, massaging her back, offering food and fluids, helping her to comfortably place herself and taking a bath, implementing pain relief measures and ghuide the woman to use breathing patterns that help her to relax. ${ }^{5}$

Scholars on the subject mention that the support for the parturient has four dimensions: emotional - through the continuous presence of a person who can encourage, praise and reassure the parturient; physical comfort - assistance in the bath, position change, massages sessions, offering fluids/foods and pain reduction; informational - explanations/guidance on what is happening and, finally, the intermediation - when the support provider interprets the woman's desires and starts to negotiate them with professionals. $^{6}$

The last systematic review published in the Cochrane Library, which assessed the benefits of support during the pre-birth and the childbirth itself, included five clinical trials that assessed the support by companion of the woman's social network, being that in three of them there were people chosen by the woman. The main presented results were: increased number of spontaneous vaginal childbirths, reduction in the use of intrapartum analgesia, decreased negative perception of women about the birth experience, reduction in the labor duration, decreased number of cesarean surgeries, decreased number of instrumental vaginal childbirths, reduction in the regional analgesia usage and decreased number of Newborns (RN) with Apgar lower than five. ${ }^{7}$

To ensure the presence of the companion in the Brazil maternities, in 2005, it was published Law $\mathrm{n}^{\circ}$ 11.108, known as the "Law of the companion"; from this moment, all healthcare services of the Unified Health System (SUS), own or associated networks were required to allow the presence of a companion of her choice during the pre-birth, childbirth and immediate postpartum. ${ }^{8}$ Nonetheless, many maternities still have 
Alves MC, Brüggemann OM, Bampi RR et al.

restrictions about this practice and do not comply with the Law. ${ }^{9}$

Thus, it is not enough to allow the presence of a companion at the Obstetric Center $(\mathrm{OC})$, since it requires that the companion is inserted in their healthcare context so that it can play its role of support provider and also have a positive experience. By considering all the previously presented aspects, we question how does occur the entry of the companion in the $O C$, what are the guidelines given to him and the support actions that it develops along with the woman that it is watching?

Accordingly, the objective of this research was to understand the insertion of the companion in the $\mathrm{OC}$ and identify the support actions to the parturient, which are developed during the prebirth, childbirth and immediate postpartum.

\section{METHODOLOGY}

This is a descriptive and exploratory survey, with a qualitative approach, developed in OC of the University Hospital from the Federal University of Santa Catarina (HU/UFSC), in the period from September to November 2011. It is worth mentioning that the aforementioned service allows and encourages the presence of a companion of the woman's choice since its implementation in $1995 .^{10}$

Participants were 17 companions (eleven husbands/partners, two sisters, two mothers, one aunt and one sister) who met the inclusion criteria, in other words, were older than 18 years and remained with parturient at least during the pre-birth or the childbirth itself. We have excluded the companions of the parturients whose fetus had a diagnosis of some type of congenital anomaly or intrauterine death. The number of participants was determined by saturation and data repetition, which was assessed by a continuous process of data analysis from the beginning of the collection. ${ }^{11}$
The support of the...

For data collection, we have used the unstructured participant observation. The observations were made in pre-birth, in the delivery room (normal or caesarean), postpartum recovery room and in the care room for the NB, based on an observation script. Besides the companions, we have observed in some instances, the healthcare professionals and the parturients, when they had interactions with the research participants.

The data registration was done in a field diary, and the notes were made after each observation, in order to record everything that happened, with a view to not undermine the data reliability. In some situations, we recorded the report of the researchers concerning the observed occurrences $^{12}$, in a reserved place to assure the confidentiality thereof. Subsequently, these recordings were transcribed. To organize the data, we have used the field notes, reflection notes and methodological notes. Routines, care procedures, professional guidelines that were made to the companions, support actions that were carried out by companions, reports obtained during the observations, as well as their expressions, were recorded in the field notes. The data interpretations were recorded in the reflection notes. And, finally, the methodological notes encompassed the points that are related to the way in which the fieldwork was conducted. ${ }^{13}$

Data were analyzed according to the proposal of Trentini and Paim ${ }^{14}$, by following four processes: seizure, synthesis, theorization and transfer.

The seizure process begins by means of data collection and information organization. The synthesis process is the part of the analysis that, subjectively, examines information associations and variations. It is necessary to return to the data worked in the seizure process and familiarize yourself with this information. In the theorization, the researcher generates and uses a theoretical

J. res.: fundam. care. online 2013. jul./set. 5(3):153-164 
Alves MC, Brüggemann OM, Bampi RR et al.

framework for understanding the information for, subsequently, performing the analysis. Finally, the transfer process is conducted, where the results should be socialized, thus enabling that the research questions are answered. ${ }^{14}$

The research met the Resolution $n^{\circ}$ 196/96 of the Brazilian Health Council, which provides for standards and ethical procedures in research involving human beings. The project was approved by the Ethics Research Committee from the UFSC, under the Protocol $n^{\circ} 2162 / 2011$. The companions were informed about the research objectives and expressed a desire to participate, by signing the Free and Informed Consent Form (FICF). In situations in which the data collection (through observation) had a member of the OC staff, we have asked its formal authorization, by signing the FICF so that the collected information could be used in the data analysis.

To assure anonymity of the participants, we have decided to use names from the Greek mythology to identify the extracts of the observations presented in the text.

\section{RESULTS AND DISCUSSION}

From the observations analysis, we have produced five categories that address aspects related to the way in which the companion is received at the $O C$ and how it supports the parturient during the childbirth's clinical periods and interacts with the NB.

\section{Category 1 - Aspects related to the insertion of a companion in the obstetric center}

The companion chosen by the woman to stay with her is usually responsible for providing the hospital admission; thus, often, it enters in the $\mathrm{OC}$ after the parturient. The guidelines on its role are usually given at the entrance time in the sector and sometimes already start in the obstetric screening. It receives a written document containing guidance on its role in the
The support of the...

$\mathrm{OC}$ and what can do and cannot do while in the sector.

\begin{abstract}
I asked if he had received guidance on his role in the $\mathrm{OC}$, he said he was told only that he would be entitled to monitor the pregnant woman during the labor, then I told him that his role was to support his wife, provide emotional and physical support to her, with massages when she wants to walk around (Achilles' Observation Extract - Husband).

I asked if she [companion] had received screening guidelines at the screening time on her role in the $\mathrm{OC}$, then she told me it is okay, that she was even signed a document with written guidance (Jocaste's Observation Extract - Mother).
\end{abstract}

To provide the initial guidelines, store belongings in the closet, show the delivery rooms and advise on the possibilities of birthing positions (vertical or horizontal) are activities provided for all parturients, along with their companions when they arrive at the OC. Moreover, such guidance on the childbirth is part of the nursing prescription. The companion should be included in the guidelines given to the woman during the labor. Studies show that it has a key role in supporting the woman, by making her more satisfied through its presence and support. ${ }^{15}$

The companion authorization, which allows it having an authorized entrance in the sector and can have the meals provided by the hospital, is provided by the $\mathrm{OC}$ nurse. The routines that permeate the presence of a companion during the pre-birth, childbirth and immediate postpartum follow the guidelines of the Normative Instruction $n^{\circ}$ 001/2009/SES/SC, which establishes guidelines for the healthcare services to conduct the insertion of a companion of the woman's free choice during the birth, childbirth and immediate postpartum. $^{16}$

The companion is instructed to stay with the woman until the immediate postpartum period, that is to say, the aim is at trying to avoid having a turnover of people. Nevertheless, depending on the situation, when, for some personal reason, it asks for leaving, the on-duty

J. res.: fundam. care. online 2013. jul./set. 5(3):153-164 
Alves MC, Brüggemann OM, Bampi RR et al.

nurse might authorize the exchange of companions. Not always the companion who is with the parturient at the admission time is the one that she wishes to remain with her until the childbirth; sometimes, the companion, after a certain admission period, is no longer able to provide an adequate support for the parturient, since it is tired, sleepy or needs to fulfill some commitment outside the hospital. Hence, it is important that there is flexibility in this routine. ${ }^{17}$, 18

\section{Category 2 - Support actions of the companion during the pre-birth}

The developed support actions are quite explicit during the pre-birth, since the dilation period is longer and the companion has more autonomy and feels more comfortable to assume its role. The continuous support of a companion or a healthcare professional helps to relieve the labor pains. ${ }^{19}$

The companion was all the time with his wife, holding her hands and showing much affection (Ares' Observation Extract Husband).

At no time, during labor, the companion left the parturient alone, he was always close to her (Perseus' Extract Observation - Husband).

Besides the continuous presence, it is important that the companion supports the parturient in some way. The most performed support actions were concerning the physical comfort and the emotional support (performing massages, monitoring the walking and helping with the therapeutic bath, assisting in the use of the Swiss ball, always being abreast of her, encouraging, reassuring and offering tenderness to the parturient) and are often simultaneously performed. These actions were also observed in a study on the companion at the pre-birth time and in the childbirth itself. ${ }^{5}$

The parturient was sitting on a Swiss ball and the companion was behind her, sitting on a small ladder, doing massages in the lumbar region (Aphrodite's Extract Observation - Aunt).
The support of the...

The parturient leaned on one of the companion's shoulders, which held her two hands and put on his shoulders. Then they hugged each other until the contraction goes by, in a gesture of emotion and complicity (Achilles' Observation Extract Husband).

In some situations, it was observed that the companion helps to explain to the parturient the guidelines given by the healthcare professional, by trying to make it simpler for her understanding. Thus, in addition to physical and emotional support, sometimes it also offers the parturient a set of information regarding the childbirth procedures and stages, which are called informational support shares. ${ }^{6}$

While oxytocin was prepared, the companion spoke to the parturient: they will put the little serum bag to help you, to make the contractions stronger (Athena's Observation Extract - Sister-in-law).

The companion asked me how many centimeters of dilation my wife had. I told him and he relayed the information to his wife with happiness (Zeus' Observation Extract - Husband).

Sometimes, the companion repeats the guidelines of the healthcare professionals, which shows that it is interacting and feels inserted in that assistential context.

The nursing academic student guided the parturient, who was squatting, with her heels apart, and explained her about the benefits. As soon as the academic left the room, the companion repeated the same guidelines to the wife (Achilles' Observation Extract - Husband).

This interaction from the companion with the $\mathrm{OC}$ professionals also allows it to express and negotiate with them the parturient's wishes, that is to say, develops support actions in order to build a intermediation. ${ }^{6}$

When the parturient asked if they would no longer hear the baby's heartbeat, the companion replied with a worrying face: She is also not feeling the baby moving anymore (Jocaste's Observation Extract - Husband).

In general, the companions participate and perform the "clearly" identified support actions, as they involve an activity. However, there are

J. res.: fundam. care. online 2013. jul./set. 5(3):153-164 
Alves MC, Brüggemann OM, Bampi RR et al.

those who are just beside the parturient, and this is a way to emotionally support the future mother. The mere presence of a well-known person, when giving support to the woman at this time of her life, contributes to the maternal satisfaction with regard to the pre-birth and the childbirth itself. ${ }^{20}$

\begin{abstract}
The companion only looked at the mother, but not touched her, did not perform massages and did not speak. The only way that they seemed to communicate was through the exchange of glances. At no time, he left the wife alone (Eros's Observation Extract - Husband).
\end{abstract}

As previously mentioned, when guided and stimulated, the companion performs actions of physical support, especially massages. But there are situations in which this does not happen due to no longer having interest from the companion and /or the parturient. This behavior type was also observed in another study, in which, in some labor moments, the companion becomes more passive than active, depending on the degree of anxiety, by requiring more encouragement and guidance from professionals. ${ }^{21}$

After being taught and encouraged to perform massages, the companion volunteered to do it. But, when the nurse walked away, he did not perform massages anymore (Diomedes' Observation Extract Husband).

When the companion feels confident and free to carry out support actions, it spontaneously performs them. In some situations, it was observed that the same does not need to be oriented to develop such actions. In such cases, the companion is considered active, as it offers safety and comfort in an autonomous way. ${ }^{21}$

\footnotetext{
The parturient was advised to stay in the knee-chest position, the husband helped her to reposition herself and when the contraction came, he seemed concerned about the welfare of his wife and, instinctively, started a massage on her lumbar region, even without being guided (Achilles' Observation Extract - Husband). During contraction, the companion wrapped a towel for her niece to bite (Aphrodite's Extract Observation - Aunt).
}

The support of the...

The physical structure and the sector's routines do not allow the companion to have meals within the OC. For feeding itself, it needs to go to the refectory or the snack bar. For fear of leaving the parturient alone, or, sometimes, to lose the childbirth moment, the companion avoids going out to eat. To alleviate this situation, occasionally, some members of the nursing staff allow the companion to feed itself within the sector by means of a diet that is not consumed by the pregnant women.

At certain times of meals, the companion
remained without food to stay beside her
wife, even she was advising him to eat
something, the guy insisted and remained
all the time at her side (Perseus'
Observation Extract - Husband).

Despite the difficulties, it was observed that the institution in which the study was developed holds strategies to assure, in one way or another, that the right to food is respected, as recommended by the Ordinance $n^{\circ} 2.418 / G M$, of December $2^{\text {nd }}, 2005$, which guarantees the payment of the companion's daily rate, which includes a suitable accommodation and the main meals. $^{22}$

\section{Category 3 - The companion's role at the childbirth time}

The companion arrives at the delivery room in a natural, by walking along with the parturient and giving her a physical support in the pathway from the pre-birth room until the labor, given that it is already dressed in apron and medical cap.

Then the patient went to the delivery room in a rambling way, but leaning on the companion's body that served as her basis (Athena's Observation Extract -Sister-inlaw).

[...] The companion showed a great feeling of happiness with the decision to go to the delivery room and followed her sister until the delivery room, being that the parturient leaned on her to walk (Artemis' Observation Extract - Sister).

In the delivery room, the nursing staff always turns to the companion, by explaining about where it should be, which is, usually, beside

J. res.: fundam. care. online 2013. jul./set. 5(3):153-164 
Alves MC, Brüggemann OM, Bampi RR et al.

the birthing chair, standing or sitting on a little stool. This position enables it to watch every delivery moments and have the first contact with the NB. The father's involvement helps him to become more committed to the family issues. ${ }^{23}$

In the delivery room, the companion stood up, coming as near as possible the parturient and having a greater physical contact in comparison to the seated position (Midas' Observation Extract Husband).

The autonomy that the companion had during the pre-birth to provide support for the parturient is reduced or ended upon entering the delivery room, because it cannot leave the place to which it was asked to stay until the childbirth moment. At the delivery time, the communication from professionals with the companion is restricted to advise where it should stay. Nevertheless, it receives guidelines during the period in which remains in the pre-birth room, which help it to understand its position and what it might do.

In the delivery room, the companion was advised to stay beside the parturient, and it was there that she remained holding the hand of her sister throughout the time (Artemis' Observation Extract - Sister).

However, it was observed that the companion still interacts with the parturient, by providing emotional support, staying abreast of her, giving tenderness, talking and encouraging her in a low voice. Each companion shows its support with its peculiarities, but those who can deal well with the situation, assume the role of protectors in spontaneous and autonomous manner. ${ }^{21}$

The companion stayed where she had been advised, she was stroking the parturient's belly and talking in a low voice, seeming to encourage her (Athena's Observation Extract -Sister-in-law).

In the delivery room, the companion remained close to the parturient, in silence, staring at his wife as if he was expecting a great happening, always in physical contact, with his hands stroking her shoulders and arms (Midas' Observation Extract - Husband).
The support of the...

In order to "help", the companion, sometimes, replays the requests from the professionals and encourages the parturient to meet them, even if they are not recommended by the WHO, since the caregiver does not have the technical knowledge to identify a practice that is not beneficial, such as the Valsalva's maneuver efforts through prolonged and directed tugs.

The companion told to the pregnant woman during contractions: be strong, strong, breathe, you must be strong to give birth to this baby (Artemis' Observation Extract - Sister).

Most companions demonstrate curiosity to see what is happening, both in the natural childbirth and in the cesarean case. The childbirth time is, generally, loaded of a lot of emotion, especially when it is the first experience of the couple. The companion participation in the labor period creates the possibility of father's involvement, by contributing to the formation of his role, as well as positively influences in the relationship with the NB and the wife. ${ }^{10}$

When the baby was being born, in a vertical and natural delivery, the companion stood up and leaned forward to see the baby coming out, and when he came out completely, the companion with a big smile on his lips began to take pictures of him in the arms of the healthcare team (Artemis' Observation Extract - Sister).

When the baby was born, the companion kissed his wife, and cried together with her. He took pictures, and asked me to take a picture of the family. Then he looks at the baby and says: How beautiful he is. Now we have a family (Ares' Observation Extract - Husband).

\section{Category 4 - The first contact between companion and newborn}

The first contact between companion and NB is visual and happens at the childbirth moment. Since the companion is beside the parturient, it can see the moment in which the entire body of the baby comes out from the mother and is held by the professional that helps in the childbirth. It becomes clear the anxiety from the companions about seeing the baby for

J. res.: fundam. care. online 2013. jul./set. 5(3):153-164 
Alves MC, Brüggemann OM, Bampi RR et al.

the first time, by reaffirming that they are emotionally involved and share the experience with the parturients. ${ }^{21}$

In cases where the NB has a good vitality, it is placed in skin-to-skin contact with the mother immediately after labor, the companion participates, celebrates the birth and, usually, takes pictures of this single moment. This is the first family meeting, which gathers the mother, the son and the companion chosen by the woman, believed to be the person that the mother considers more special for seeing that moment, regardless of having or not kinship ties. When the companion is the father, the early contact with his child can strengthen the family bonds. ${ }^{24}$

[...] The companion began to take pictures of the NB even when he was being dried and also when he was delivered to his mother for conducting the first skin-to-skin contact. When the NB was already in the mother's lap, the companion continued to take pictures and pamper her nephew, showing affection and satisfaction (Artemis' Observation Extract - Sister).

When the newborn is brought to the care room, the companion is always invited to go along to witness the attendance. In this situation, the companion tries to divide itself because of two choices: giving attention to the newly puerperal woman and accompany the NB. The companion is one that replaces the woman when she cannot be together with the child, by assuming this role as an adjuvant in the care. ${ }^{25}$

\begin{abstract}
The newborn was taken to the care room intended to be heated, but his father preferred to stay with his wife at that time. While the episiorrhaphy was being conducted, the anxious companion asked if he could see the baby, and was accompanied until the room in which the NB was (Midas' Observation Extract Husband).
\end{abstract}

The bath, measures and medications are conducted by the nursing team, which sometimes, offers the companion the opportunity to perform the first bath. Generally, the companions take pictures, touch, as well as talk to the NB and to the healthcare staff, by showing a great J. res.: fundam. care. online 2013. jul./set. 5(3):153-164
The support of the...

satisfaction after birth. Study on care actions developed by the father in the puerperium states the man wants to feel father of that child, being that the bonds begin to emerge in such a moment. ${ }^{26}$

The companion remained next to the baby all the time and photographed several moments, as the first bath, weighing, measures of height and perimeters (Artemis' Observation Extract - Sister). After performing the first baby care procedures, the nursing technician offered the companion the opportunity to perform the first bath, she accepted and then smiling - participated in this too symbolic gesture (Jocaste's Observation Extract Mother).

The first family lap is usually from the companion, who is responsible for taking the NB from the care room until to the postpartum recovery room, where the baby awaits the arrival of the puerperal woman, in cases where she has not yet returned from the delivery room.

[...] After bathing, the NB went to her aunt's lap, who led him to the recovery room for conducting the meeting between mother and son (Artemis' Observation Extract - Sister).

Based on the $\mathrm{WHO}^{4}$ recommendations and following the philosophy of the HU/ UFSC maternity, the companion is encouraged not only to witness the childbirth process, but also participate in such a moment. ${ }^{27}$ When the companion participates in the whole childbirth process, there is increase in the family bond and strengthening of the emotional ties between caregiver and $\mathrm{NB} .{ }^{28}$

In the attendance room, the companion watched his son from afar and seeming worried, then the team encouraged him to get closer and touch the NB, then he came up a little shy and began stroking him (Midas' Observation Extract - Husband).

In situations where there is a complication with the NB, the companion does not participate in the first care procedures and stays with his wife in the delivery room until there is a clinical stabilization. During the complications, the presence of the companion does not interfere in 
Alves MC, Brüggemann OM, Bampi RR et al.

the care, despite the healthcare professionals reporting a greater anxiety to solve the situation. $^{29}$

After birth, the baby was quickly taken to the care room of the NB, where he was ventilated and monitored until he showed an improvement in the cardiopulmonary system, when everything was well, the team called the companion, who came very concerned to see his daughter (Perseus' Observation Extract - Husband).

Category 5 - The interaction from the companion with the binomial in the immediate postpartum

The support from the companion in the immediate postpartum period, in the recovery room, is more related to the aid during the breastfeeding and in holding the NB. It should be observed that, in this location, the interaction from the companion with the binomial takes place with greater freedom and spontaneity, given that, often, informs the relatives by telephone about the birth. The companion starts to rehearse the support that it will provide to the woman in the late puerperium, by meeting her requests, wishes and needs. ${ }^{26}$

The companion helped the puerperal woman to put the baby to suck, when asked if he had a good sucking, the companion replied me with pride, by saying that she [companion] had put the baby to breastfeed (Athena's Observation Extract - Sister-in-law).

The recovery room is where the woman is enabled to rest for the first time after the childbirth. It was observed that the companion helps in issues to which it feels able, exchanges caresses with the puerperal woman, takes care of the NB, and the main issue, shares the feeling of happiness and satisfaction with the woman. He also has the opportunity to expose the concerns that he had during the childbirth process. In the postpartum, the companion's performance is extended beyond the care of the woman, as now he also covers the care of the NB. ${ }^{30}$

In the recovery room, when we saw all the three together [puerperal woman, companion and NB] the companion told -
The support of the...

confidentially - to the puerperal woman that was willing to pull the baby's little head at the childbirth time, because it seemed that it would be suffocated (Aphrodite's Observation Extract - Aunt).

The companion helps with the care of the NB, especially holding it on its lap, in order to let the puerperal woman free to be cared. During the emergency care to the woman, the companion can help, when holding the NB, and enabling the healthcare staff to focus all attention on the woman. This situation helps to deconstruct the idea that the companion could disrupt the team, by agreeing with other studies that argue the same idea. ${ }^{29}$

While the puerperal woman received the emergency care, she asked her husband to hold the baby and he immediately answered, stayed with the baby in his lap and next to the wife's bed, but far enough to not interfere with the movement of the healthcare team, and without forgetting to look at his wife with an expression of concern, he walked from one side to the other with the NB in his lap (Achilles' Observation Extract - Husband).

\section{CONCLUSION}

The insertion of a companion in the $\mathrm{OC}$ is, occasionally, preceded by information that is given in the obstetric screening, but the guidelines on its role are usually conducted when it enters in the sector.

Although some companions develop several types of support actions (physical comfort, intermediation and informational), the most developed are those that include the emotional support, ranging from fondling, words of affection and courage, exchange of glances, holding the parturient's hands to stay close to her all the time. During the labor time, when the parturient is still in the pre-birth stage, the companion has more autonomy and can often develop the actions of physical and emotional comfort, but also provides a significant support in the childbirth and in the postpartum period. By the time the parturient is taken to the delivery room, the

J. res.: fundam. care. online 2013. jul./set. 5(3):153-164 
Alves MC, Brüggemann OM, Bampi RR et al.

autonomy that the companion had during the labor is extinguished and is only rescued in the immediate postpartum phase.

The companion also have the opportunity to early interact with the NB and monitor its attendance in the care room, which provides a certain safety and tranquility for the woman who is unable to do such actions, in the other words, it assumes the role of "guardian" of the her son.

This current study provides grants for expanding the understanding of how is the insertion and length of the companion in the daily life of the OC. Furthermore, it allows the identification and recognition of support actions provided for the parturient, which might contribute to the development of strategies that encourage and facilitate its participation in a more effective way.

\section{REFERENCES}

1. Tanaka ACA. Maternidade: dilema entre nascimento e morte. São Paulo: Editora Hucitec/Rio de Janeiro: ABRASCO, 1995.

2. Nagahama EEI, Santiago SM. A institucionalização médica do parto no Brasil. Ciênc. saúde coletiva. 2005 [acesso em: 20 nov. 2011] $10 \quad$ (3): 651-57. Disponível em: http://www.scielosp.org/pdf/csc/v10n3/a21v 10n3.pdf

3. Osava RH. Assistência ao parto no Brasil: 0 lugar dos não médicos [tese]. São Paulo: Faculdade de Saúde Pública da Universidade de São Paulo; 1997.

4. Organização Mundial da Saúde. Assistencia ao parto normal: um guia prático. Genebra: OMS; 1996.

5. Oliveira AS, Rodrigues DP, Guedes MVC, Felipe GF, Galiza FT, Monteiro LC. O acompanhante no momento do trabalho de parto e parto: percepção de puérperas. Cogitare Enfermagem. 2011. J. res.: fundam. care. online 2013. jul./set. 5(3):153-164
The support of the...

[acesso em: 20 nov. 2011] 16 (2): 247-53. Disponível em: http://ojs.c3sl.ufpr.br/ojs2.2.4/index.php/cogitare/article/view/20201/142 11

6. Hodnett ED, Osborn RW. Effects of continuous intrapartum professional support on childbirth outcomes. Res Nurs Health. 1989; 12: 298-97.

7. Hodnett ED. Gates S, Hofmeyr GJ, Sakala C. Continuous support for women during childbirth. (Cochrane Review). [online]. 2011. [acesso em: 12 set. 2011] Disponível em: Disponível em: http://www2.cochrane.org/reviews/en/ab003766 .html

8. Brasil. Congresso Nacional. Lei n. 11.108, de 07

de abril de 2005. Altera a Lei n. 8.080, de 19 de setembro de 1990, para garantir às parturientes 0 direito à presença de acompanhante durante o trabalho de parto, parto e pós-parto imediato, no âmbito do Sistema Único de Saúde. Diário Oficial da União, Brasília. 8 abr. 2005.

9. Nagahama EEI, Santiago SM. Parto humanizado e tipo de parto: avaliação da assistência oferecida pelo Sistema Único de Saúde em uma cidade do sul do Brasil. Rev. Bras. Saude Mater. Infant. 2011 [acesso em: 20 fev. 2012], 11 (4): 415-25. Disponível em:

10. Santos OMB, Siebert ERC. The humanization of birth experience at the University of Santa Catarina maternity hospital. Int J Gynecol Obstetricy. 2001 [acesso em: 08 nov. 201] 75 (1): 73-90.

Disponível em:http://www.ncbi.nlm.nih.gov/pubmed/11742 646

11. Fontanella BJB, Ricas J, Turano ER. Amostragem por saturação em pesquisa qualitativa em saúde: contribuições teóricas. Cad. Saúde Pública. 2008 [acesso em: 18 nov. 2011] 24 (1): 17-27. Disponível em: http: / / www.scielo.br/pdf/csp/v24n1/02.pdf 
12. Silverman D. Interpretação de dados qualitativos: métodos para análise de entrevistas, textos e Interações. 3 ed. Porto Alegre: Artmed;2009.

13. Monticelli M. Aproximações culturais entre trabalhadoras de enfermagem e famílias, no contexto do nascimento hospitalar: uma etnografia do Alojamento Conjunto [tese]. Florianópolis: Programa de Pós-graduação em Enfermagem, Universidade Federal de Santa Catarina; 2003.

14. Trentini M, Paim LMD. Pesquisa convergenteassistencial: um desenho que une o fazer e o pensar na prática assistencial em saúdeenfermagem. 2 ed. Florianópolis: Insular, 2004.

15. Brüggemann $\mathrm{OM}$, Parpinelli $M A$, Osis MJD, Cecatti JG, Carvalhinho Neto AS. Support to woman by a companion of her choice during childbirth: a randomized controlled trial. Reproductive Health. 2007 [acesso em 01 set. 2011]. 4 (1): 7p. Disponível em: http: / / www.reproductive-health

journal.com/content/4/1/5

16. Santa Catarina. Instrução Normativa $n^{\circ}$ 001/2009/SES, de 06 de abril de 2009. Estabelece diretrizes para os serviços de saúde efetivarem a inserção do acompanhante de livre escolha da mulher durante o trabalho de parto, parto e pósparto imediato. Diário Oficial do Estado, Santa Catarina, n.18.667, 12 ago. 2009.

17. Torquinst CS. Paradoxos da humanização em uma maternidade do Brasil. Caderno de Saúde Pública. 2003 [acesso em: 21 nov. 2011]. 19 (Sup 2): S419-S427. Disponível em: http://www.scielo.br/pdf/csp/v19s2/a23v19s2.pd $\mathrm{f}$

18. Nakano AMS, Silva LA, Beleza ACS, Stefanello J, Gomes FA. O suporte durante o processo de parturição: a visão do acompanhante. Rev. Acta Paulista Enfermagem. 2007 [acesso em: 01 out. 2011]. 20 (2): 131-37. Disponível em: http: / / www.scielo.br/pdf/ape/v20n2/a04v20n2.p df

19. Silva AVR, Siqueira AAFD. O valor do suporte à parturiente: um estudo da relação interpessoal no contexto de um Centro de Parto Normal. Rev. Bras. Crescimento Desenvolv. Humano. 2007 [acesso em: 19 nov. 2011]. 17 (1): 126-35. Disponível em: http: / / pepsic.bvsalud.org/pdf/rbcdh/v17n1/12.p df

20. Domingues RMSM, Santos EM, Leal MC. Aspecto da satisfação das mulheres com a assistência ao parto: contribuição para o debate.Cad. Saúde Pública. 2004 [acesso em: 21 nov.2011].20 (1): 5262. Disponível em:

http: / / www.scielo.br/pdf/csp/v20s1/06.pdf

21. Motta CCL, Crepaldi MA. O pai no parto e o apoio emocional: a perspectiva da parturiente. Paidéia - Cadernos de Psicologia e Educação. 2005 [acesso em: 19 nov. 2011]. 15 (30): 105-18. Disponível

em: http: / / www.scielo.br/pdf/paideia/v15n30/12.pdf 22. Brasil. Gabinete do Ministro. Portaria n. 2.418/GM de 02 de dezembro de 2005. Regulamenta, em conformidade com o art. $1^{\circ} \mathrm{da}$ Lei $n^{\circ} 11.108$, de 7 de abril de 2005, a presença de acompanhante para mulheres em trabalho de parto, parto e pós-parto imediato nos hospitais públicos e conveniados com o Sistema Único de Saúde. Diário Oficial da União, Brasília, 06 de dezembro de 2005. Disponível em: <http://dtr2001.saude.gov.br/sas/PORTARIAS/Por t2005/GM/GM-2418.htm> Acesso em: 21 nov. 2011.

23. Hoga LAK, Pinto CMS. Assistência ao parto com a presença do acompanhante: Experiências de profissionais. Rev. Investigación y Educación en Enfermería. 2007 [acesso em: 19 nov. 2011]. 25 (1): 74-81. Disponível em: http: / / redalyc.uaemex.mx/src/inicio/ArtPdfRed.j sp?iCve=105216848008 
Alves MC, Brüggemann OM, Bampi RR et al.

24. Hotmsky SN, Alvarenga ATA. Definição do acompanhante no parto: uma questão ideológica?Rev. Estud. Feministas. 2002 [acesso em: 14 nov. 2011]. 10 (2): 461-81. Disponível em: http://www.scielo.br/pdf/ref/v10n2/14971.pdf

25. Cardinali F, Aires LCP, Monticelli M, Correia DS, Mendes L, Alcântara MG . O acompanhante no alojamento conjunto da maternidade. Rev. Enferm. UFSM. 2011 [acesso em: 20 nov. 2011]. 1 (1): 1-14. Disponível em: http: //cascavel.ufsm.br/revistas/ojs-

2.2.2/index. php/reufsm/article/view/2407/1506.

26. Oliveira EMF, Brito RS. Ações de cuidado desempenhadas pelo pai no puerpério. Esc. Anna Nery Rev. Enfermagem. 2009 [acesso em: 20 nov. 2011]. 13 (3): 595-601. Disponível em: http://www.scielo.br/pdf/ean/v13n3/v13n3a20.p df

27. Monticelli $M$, Brüggemann $O M$, Guerini IC, Boing AF, Padilha MF, Fernandes VB. A filosofia assistencial da maternidade de um Hospital Universitário na visão dos acadêmicos. Rev. Texto Contexto Enfermagem. 2010 [acesso em: 20 nov. 2011]. 19 (1): 25-35. Disponível em: http: //www.scielo.br/pdf/tce/v19n1/v19n1a03.df 28. Junckes JM, Guesser JC, Zampieri MFM, Gregório VRP, Oliveira ZC, Regis I. Grupo de gestantes e/ou casais grávidos e a inserção do acompanhante/pai no processo de nascimento. Extensio: Revista Eletrônica de Extensão. 2009 [acesso em 09 de nov. de 2011]. 6 (7): 55-72. Disponível em: http://www.periodicos.ufsc.br/index.php/extensi o/article/view/10918/10485

29. Brüggemann OM, Osis MJD, Parpinelli MA. Apoio no nascimento: percepções de profissionais e acompanhantes escolhidos pela mulher. Rev. Saúde Pública. 2007 [acesso em: 21 nov. 2011]. 41(1): 44-52. Disponível em: http: / /www.scielosp.org/pdf/rsp/v41n1/5409.pdf 30. Longo CSM, Andraus LMS, Barbosa MA. Participação do acompanhante na humanização do J. res.: fundam. care. online 2013. jul./set. 5(3):153-164
The support of the...

parto e sua relação com a equipe de saúde. Rev. Eletr. Enfermagem. 2010 [acesso em: 10 set. 2011]. 12 (2): 386-91. Disponível em: http: / / www.fen.ufg.br/revista/v12/n2/v12n2a25. htm

Received on: 20/06/2012

Reviews required: No

Approved on: 18/01/2013

Published on: 01/07/2013 